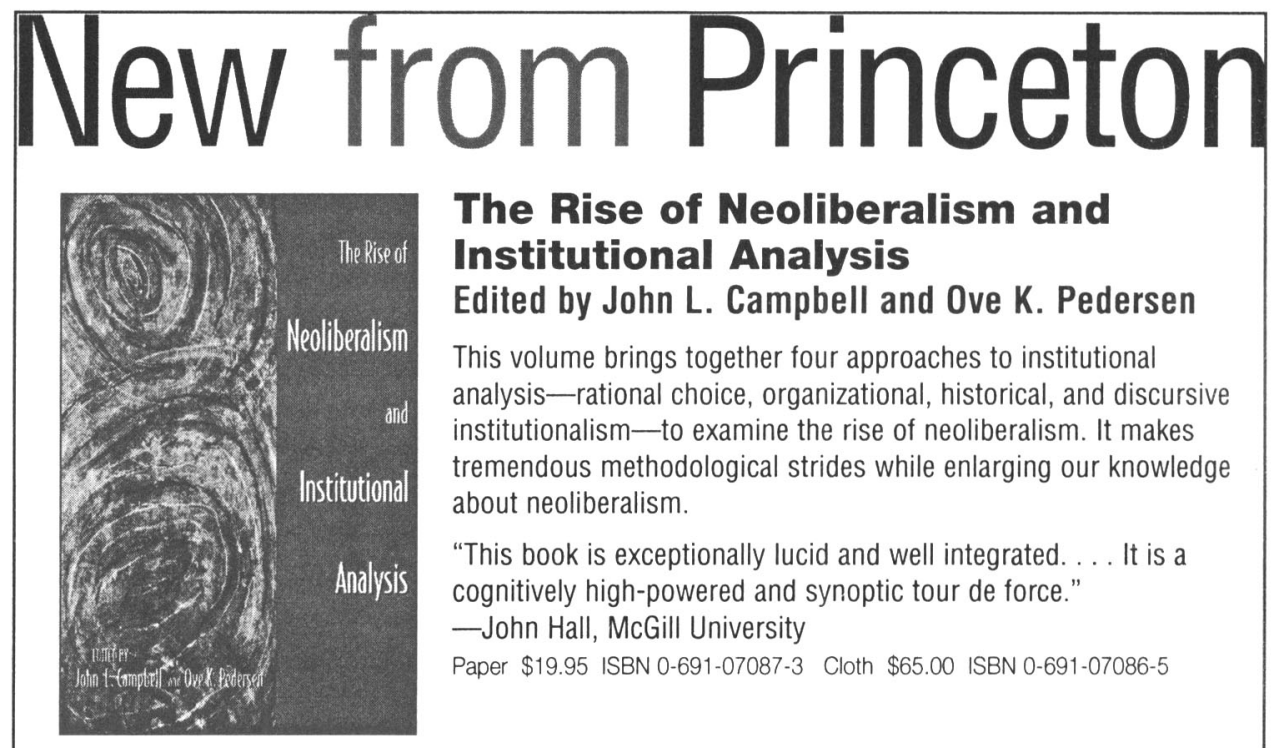

\title{
The Helsinki Effect
}

International Norms, Human Rights, and the Demise of Communism

\section{Daniel C. Thomas}

Human rights norms do matter. Those established by the Helsinki Final Act contributed directly to the demise of communism in the former East bloc, contends Daniel Thomas.

"Thomas has done a great job showing how the Helsinki human rights norms mattered.... The writing is excellent. The story is compelling."-Stephen D. Krasner, Stanford University

Paper \$18.95 ISBN 0-691-04859-2 Cloth \$49.50 ISBN 0-691-04858-4
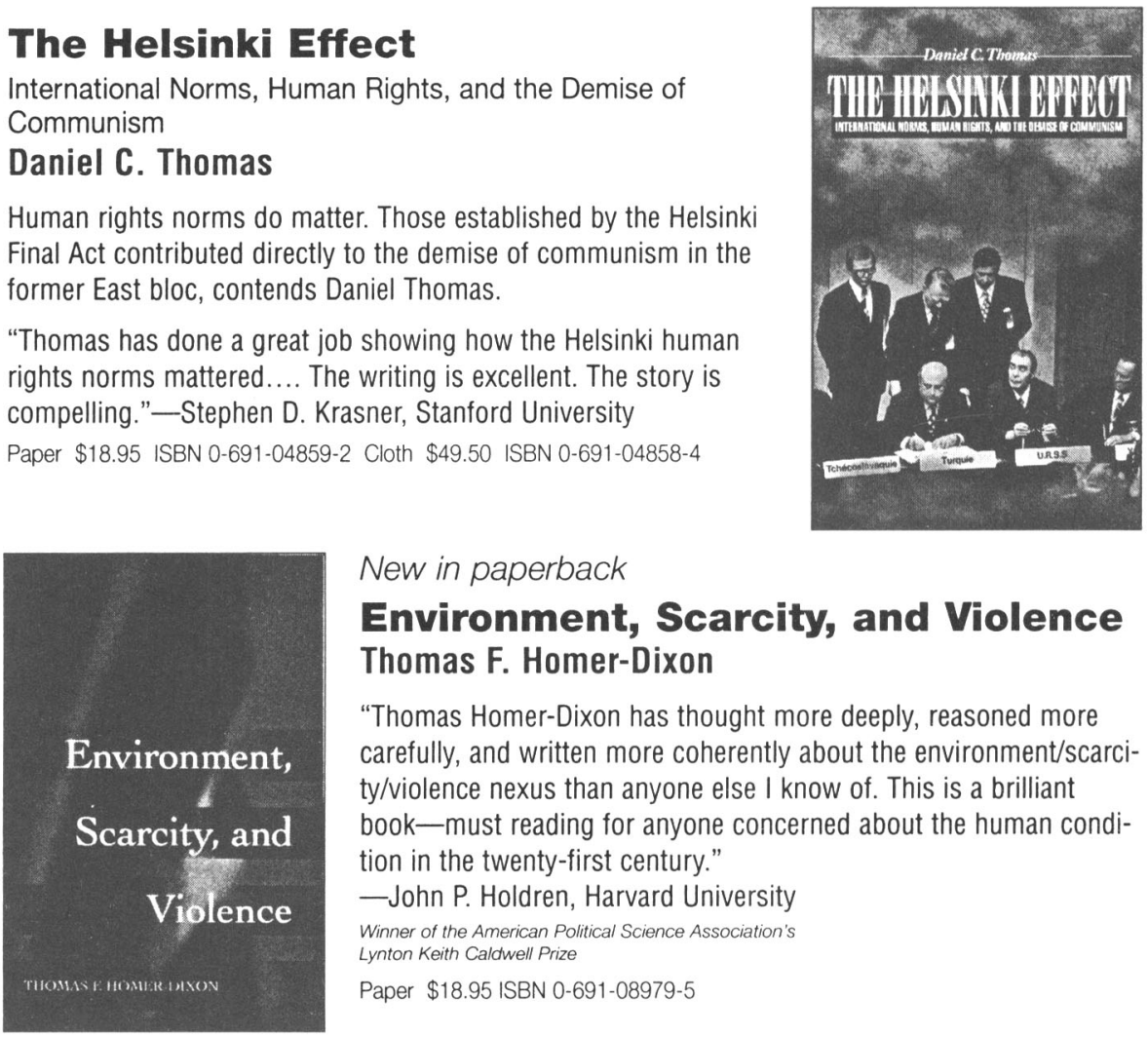

New in paperback

\section{Environment, Scarcity, and Violence} Thomas F. Homer-Dixon

"Thomas Homer-Dixon has thought more deeply, reasoned more carefully, and written more coherently about the environment/scarcity/violence nexus than anyone else I know of. This is a brilliant book - must reading for anyone concerned about the human condition in the twenty-first century."

-John P. Holdren, Harvard University

Winner of the American Political Science Association's Lynton Keith Caldwell Prize

Paper \$18.95 ISBN 0-691-08979-5

\section{Фఠ Princeton University Press}




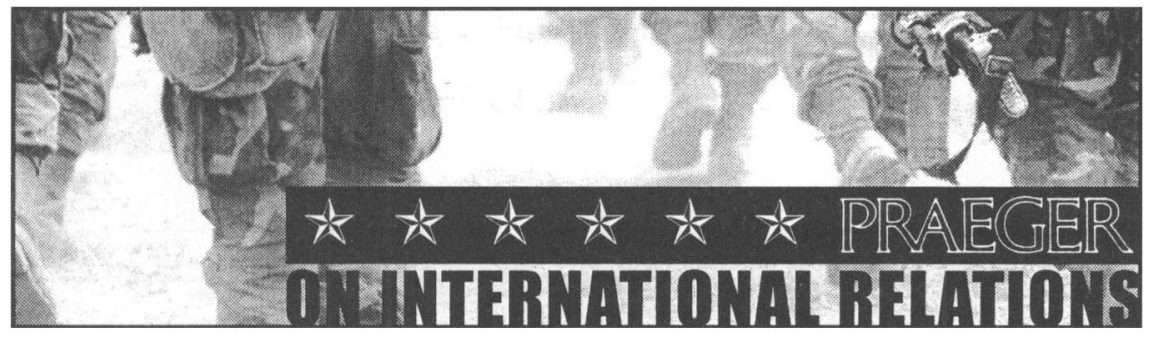

\section{Of Fears and Foes}

Security and Insecurity in an

Evolving Global Political Economy

Edited by Jose V. Ciprut

Reexamines one of the cornerstones

of international relations theory-

the concept of security.

Praeger Paperback • $2001 \cdot 288$ pages

0-275-97575-4 • \$25.00

A hardcover edition is available:

0-275-96855-3 • \$72.50

\section{Unequal Partners}

\section{French-German Relations,}

\section{9-2000}

\section{By Julius W. Friend}

Foreword by Simon Serfaty

Published with the Center for Strategic

and International Studies, Washington, D.C.

The Washington Papers, No. 180

Examines the decade of French-German relations since the reunification of Germany.

"This is an excellent and very useful book. It is a concise, accurate narrative of the past 10 years in French-German relations-all in one place and up to date. Policymakers wishing to acquire a better sense of these relations today would definitely benefit by consulting it." Philip Gordon, Director

Center on the United States and France

Praeger Paperback • 2002

0-275-97603-3 • \$20.00

A hardcover edition is available:

$0-275-97602-5 \cdot \$ 55.00$

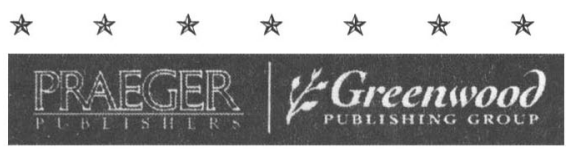

Praeger is a imprint of the Greenwood Publishing Group

\section{Putting "Defense" Back into U.S. Defense Policy Rethinking U.S. Security in the Post-Cold War World By Ivan Eland}

Challenges the prevailing interventionist mentality of the American foreign policy establishment, and presents the political and economic arguments for a policy of military restraint overseas.

Praeger Publishers • $2001 \cdot 256$ pages 0-275-97348-4 • \$39.95

\section{The Third Option}

\section{The Emancipation of}

European Defense, 1989 - 2000

By Charles G. Cogan

Humanistic Perspectives on International Relations

Asserting its own strategic identity vis-à-vis NATO, the EU struggles to make its military and diplomatic influence match its impending economic might.

"Dr. Cogan cogently highlights the problems of NATO and the European Union becoming two separate and potentially competing defense organizations in Europe. His study is essential reading for anyone wanting to understand European defense issues and transatlantic security relations."

Samuel P. Huntington

Albert J. Weatherhead III University Professor Harvard University

Praeger Publishers • $2001 \cdot 200$ pages 0-275-96948-7 • \$59.95

* * * * * * * * *

88 Post Road West - P.O. Box 5007 Westport, CT 06881-5007 Order Fax (203) 750-9790

PLACE YOUR ORDER TOLL-FREE: 1-800-225-5800 WWW.greenwood.com 
United States Postal Service

Statement of Ownership, Management, and Circulation

\begin{tabular}{|c|c|c|c|c|c|c|c|c|c|c|}
\hline \multirow{2}{*}{$\begin{array}{l}\text { 1. Publication Title } \\
\text { IO, International Organization }\end{array}$} & \multicolumn{9}{|c|}{ 2. Publication Number } & \multirow{2}{*}{$\begin{array}{r}\text { 3. Filing Date } \\
10 / 01 / 01\end{array}$} \\
\hline & 0 & 0 & 2 & 0 & - & 8 & 1 & 8 & 3 & \\
\hline $\begin{array}{l}\text { 4. Issue Frequency } \\
\text { Quarterly: Winter/Spring/Summer/Autumn }\end{array}$ & \multicolumn{9}{|c|}{$\begin{array}{l}\text { 5. Number of Issues Published Annually } \\
\text { four }\end{array}$} & $\begin{array}{l}\text { 6. Annual Subscription Price } \\
\$ 42 / 1 N D, \$ 135 / I N S T\end{array}$ \\
\hline \multicolumn{10}{|c|}{$\begin{array}{l}\text { 7. Complete Mailing Address of Known Office of Publication (Not printer) (Street, city, county, state, and ZIP+4) } \\
\text { MIT Press, Five Cambridge Center, Cambridge, Middlesex, MA 02142-1407 }\end{array}$} & \begin{tabular}{|l|}
$\begin{array}{l}\text { Contact Person } \\
\text { Lori White }\end{array}$ \\
Telephone \\
$617-258-6863$
\end{tabular} \\
\hline
\end{tabular}

9. Full Names and Complete Mailing Addresses of Publisher, Editor, and Managing Editor (Do not leave blank)

Publisher (Name and complete mailing address)

MIT Press, Five Cambridge Center, Cambridge, MA 02142-1407

\section{Editor (Name and complete mailing address)}

Peter Gourevitch \& David Lake, Graduate School of Intl Relations, Univ of CA, San Diego, 9500 Gilman Dr, LaJolla, CA 92093-0519 Managing Editor (Name and complete mailing address)

Lynne Bush, Graduate School of Intl Relations, Univ of CA, San Diego, 9500 Gilman Dr, LaJolla, CA 92093-0519

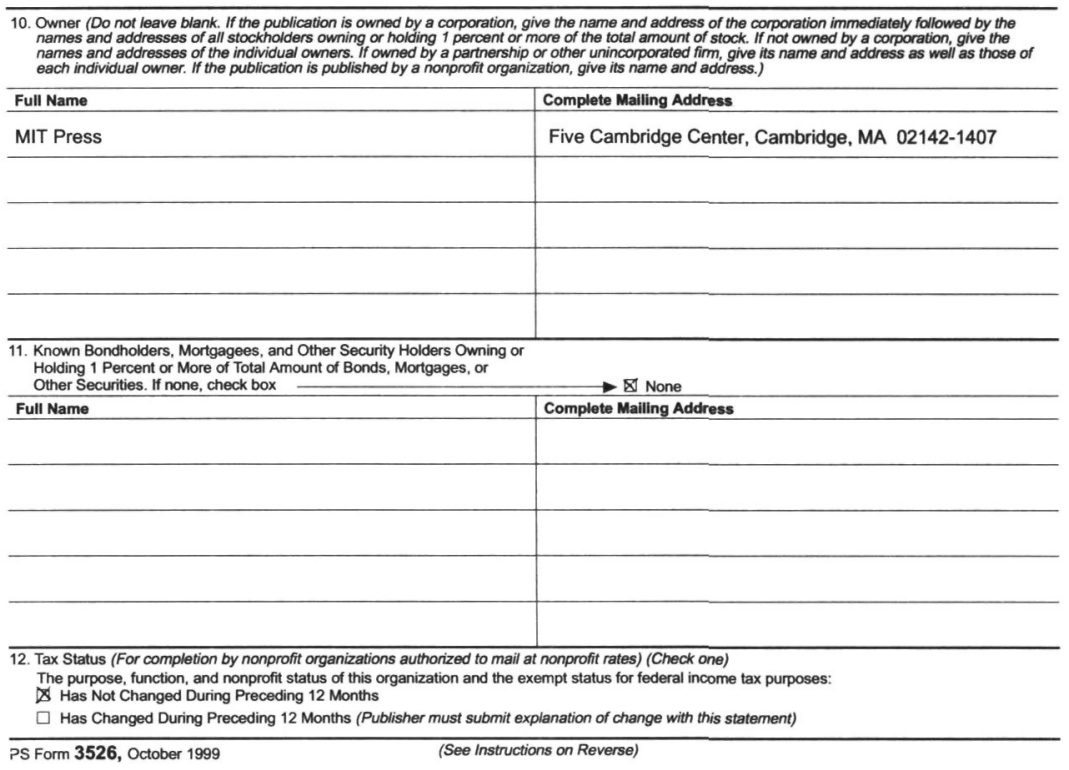




\begin{tabular}{|c|c|c|c|c|}
\hline \multicolumn{3}{|c|}{$\begin{array}{l}\text { 13. Publication Title } \\
\text { IO, International Organization }\end{array}$} & \multicolumn{2}{|l|}{$\begin{array}{l}\text { 14. Issue Date for Circulation Data Below } \\
\text { 55:3, Summer } 2001\end{array}$} \\
\hline \multicolumn{2}{|c|}{15.} & Extent and Nature of Circulation & $\begin{array}{l}\text { Average No. Copies Each Issue } \\
\text { During Preceding } 12 \text { Months }\end{array}$ & $\begin{array}{l}\text { No. Copies of Single Issue } \\
\text { Published Nearest to Filing Date } \\
\end{array}$ \\
\hline \multicolumn{3}{|c|}{ a. Total Number of Copies (Net press run) } & 3426 & 3375 \\
\hline \multirow{4}{*}{$\begin{array}{l}\text { b. Paid and/or } \\
\text { Requested } \\
\text { Circulation }\end{array}$} & (1) & $\begin{array}{l}\text { Paid/Requested Outside-County Mail Subscriptions Stated on } \\
\text { Form 3541. (Include advertiser's proof and exchange copies) }\end{array}$ & 1749 & 1905 \\
\hline & (2) & $\begin{array}{l}\text { Paid In-County Subscriptions Stated on Form } 3541 \\
\text { (Include advertiser's proof and exchange copies) }\end{array}$ & & . \\
\hline & (3) & $\begin{array}{l}\text { Sales Through Dealers and Carriers, Street Vendors, } \\
\text { Counter Sales, and Other Non-USPS Paid Distribution }\end{array}$ & 731 & 811 \\
\hline & (4) & Other Classes Mailed Through the USPS & & \\
\hline \multicolumn{3}{|c|}{$\begin{array}{l}\text { c. Total Paid and/or Requested Circulation } \\
\text { [Sum of } 15 b .(1),(2),(3) \text {, and }(4)]\end{array}$} & 2480 & 2716 \\
\hline \multirow{3}{*}{$\begin{array}{l}{ }^{d} \text { Free } \\
\text { Distribution } \\
\text { by Mail } \\
\text { (Samples, } \\
\text { compliment } \\
\text { ary, and } \\
\text { other free) }\end{array}$} & (1) & Outside-County as Stated on Form 3541 & 68 & 72 \\
\hline & (2) & In-County as Stated on Form 3541 & & \\
\hline & (3) & Other Classes Mailed Through the USPS & & \\
\hline \multicolumn{3}{|c|}{$\begin{array}{l}\text { e. Free Distribution Outside the Mail } \\
\text { (Carriers or other means) }\end{array}$} & 40 & 39 \\
\hline \multicolumn{3}{|c|}{ f. Total Free Distribution (Sum of 15d. and 15e.) } & 108 & 111 \\
\hline \multicolumn{3}{|c|}{ Total Distribution (Sum of $15 \mathrm{C}$. and $15 f$ ) } & 2588 & 2827 \\
\hline \multicolumn{3}{|c|}{ Copies not Distributed } & 838 & 548 \\
\hline \multicolumn{3}{|c|}{ i. Total (Sum of $15 \mathrm{~g}$. and $\mathrm{h}$. ) } & 3426 & 3375 \\
\hline \multicolumn{3}{|c|}{$\begin{array}{l}\text { i. Percent Paid and/or Requested Circulation } \\
\text { (15c. divided by 15g. times 100) }\end{array}$} & $96 \%$ & $96 \%$ \\
\hline \multicolumn{5}{|c|}{$\begin{array}{l}\text { 16. Publication of Statement of Ownership } \\
\qquad \text { Publication required. Will be printed in the Autumn 2001, 55:4_ issue of this publication. }\end{array}$} \\
\hline \multicolumn{4}{|c|}{ 17. Signature ang Title of Editor, Publisher, Business Manager, or Owner } & $\begin{array}{l}\text { Date } \\
\qquad 10 / 1 / 01\end{array}$ \\
\hline
\end{tabular}

I certify that all information furnished on this form is true and complete. I understand that anyone who furnishes false or misleading information on this form or who omits material or information requested on the form may be subject to criminal sanctions (including fines and imprisonment) and/or civil sanctions (including civil penalties).

\section{Instructions to Publishers}

1. Complete and file one copy of this form with your postmaster annually on or before October 1. Keep a copy of the completed form for your records.

2. In cases where the stockholder or security holder is a trustee, include in items 10 and 11 the name of the person or corporation fo whom the trustee is acting. Also include the names and addresses of individuals who are stockholders who own or hold 1 percent or more of the total amount of bonds, mortgages, or other securities of the publishing corporation. In item 11, if none, check the box. Use blank sheets if more space is required.

3. Be sure to furnish all circulation information called for in item 15. Free circulation must be shown in items $15 d, e$, and $f$.

4. Item 15h., Copies not Distributed, must include (1) newsstand copies originally stated on Form 3541, and returned to the publisher. (2) estimated returns from news agents, and (3), copies for office use, leftovers, spoiled, and all other copies not distributed.

5. If the publication had Periodicals authorization as a general or requester publication, this Statement of Ownership, Management, and Circulation must be published; it must be printed in any issue in October or, if the publication is not published during October, the first issue printed after October.

6. In item 16, indicate the date of the issue in which this Statement of Ownership will be published.

7. item 17 must be signed.

Failure to file or publish a statement of ownership may lead to suspension of Periodicals authorization.

PS Form 3526, October 1999 (Reverse) 


\section{Keep informed with \\ International Organization}

Whether your main interest is in international relations, business, or finance, you can't afford to be without the timely, authoritative, and influential articles in INTERNATIONAL ORGANIZATION. Order your personal subscription today and join the experts in universities, embassies, corporations, and international think tanks who must read INTERNATIONAL ORGANIZATION to keep informed of today's shifting alliances and international market activity. The full text of $I O$ is now available online from The MIT Press. For an additional $\$ 50$ annual fee, individual subscribers can now access 10 back volumes 1 to 50 available online from $J S T O R$.

This is a new subscription.

- This is a renewal. My account number is (see label)

Your subscription will begin with vol. 56, No. 1 (Winter 2002).

_ This is a gift. (Please attach recipient's name/address as well as your own.)

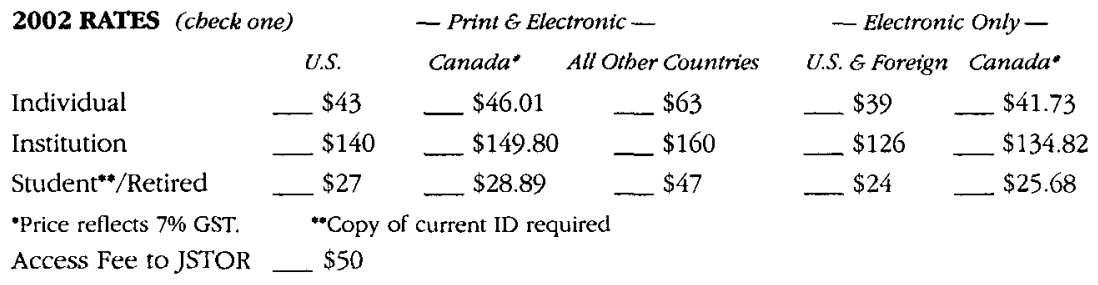

\section{Prepayment required}

Check or money order enclosed, payable to International Organization.

(check must be drawn against a U.S. bank in U.S. funds)

Charge to my __ MasterCard ___ VISA AmEx
Account No.___ Expiration Date
Signature
Print cardholder's name

Send the subscription to: (please print clearly)

Name ___ Daytime phone

Company/Dept. ___ E-mail

Address

City/State/Province/Zip/Country IOBM02

For ordering information on back issues, contact:

Circulation Department

MIT Press Journals

Five Cambridge Center

Cambridge, MA 02142

Tel: 617-253-2889

Fax: 617-577-1545

journals-orders@mit.edu

http://mitpress.mit.edu/IO
To subscribe, send this form with your payment to the Circulation Department at the address at left or order by pbone, fax or email. 


\section{International Organization}

Volume 55 Number 4 Autumn 2001

International Organization (ISSN 0020-8183) is published quarterly (winter, spring, summer, and autumn) by The MIT Press, Five Cambridge Center, Cambridge, MA 02142-1407. An electronic, full-text version of IO is available from the MIT Press. Subscriptions and address changes should be addressed to MIT Press Journals, Five Cambridge Center, Cambridge, MA 02142-1407; telephone (617) 253-2889; fax (617) 577-1545; e-mail: journalsorders@mit.edu. Subscriptions are on a volume year basis. Subscription rates: Electronic only-Individuals $\$ 39.00$, Students/retired $\$ 24.00$. Institutions $\$ 126.00$. Canadians add $7 \%$ GST. Print and Electronic-Individuals \$43.00, Students/retired \$27.00. Institutions $\$ 140.00$. Outside the U.S. and Canada add $\$ 20.00$ for postage and handling. Canadians add the 7\% GST. Single Issues-Current issues are $\$ 14.00$. Back issue rates: Individuals $\$ 19.00$, Institutions $\$ 38.00$. Outside the U.S. and Canada add $\$ 5.00$ for postage and handling. Canadians add $7 \%$ GST. For an additional $\$ 50.00$ annual fee, individual subscribers can access 10 back volumes $1-49$, available online from JSTOR. Claims for missing issues will be honored free of charge if made within three months after the publication date of the issue. Claims may be submitted to: journals-claims@mit.edu. Prices subject to change without notice. Postmaster: Send address changes to International Organization, Five Cambridge Center, Cambridge, MA 02142-1407. Periodicals postage paid at Boston and additional mailing offices.

International Organization is abstracted or indexed in the following: Academic Abstracts, ABC Pol Sci, America: History and Life, Communication Abstracts, Current Contents/Social \& Behavioral Sciences, Current Law Index, Deep Sea Research \& Oceanographic Abstracts, Energy Research Abstracts, Expanded Academic Index, Future Survey, Historical Abstracts, Human Rights Internet Reporter, INIS Atomindex, Index of Economics Articles, International Bibliography of Economics (also in IBSS), International Bibliography of Periodical Literature, International Bibliography of the Social Sciences/Political Science, International Labour Documentation, International Political Science Abstracts, Journal of Economic Literature, Key to Economic Science, Legal Research Index, Magazine Index (Information Access Company), Middle East: Abstracts and Index, Public Affairs Information Service/ PAIS, Recently Published Articles, Rural Recreation and Tourism, SCIMP (Selective Cooperative Index of Management Periodicals), Social Sciences Citation Index, Social Sciences Index, Social Science Source, Sociological Abstracts, World Agricultural Economics \& Rural Sociology Abstracts.

Advertising and mailing list rental: Please write to Marketing Department, MIT Press Journals, Five Cambridge Center, Cambridge, MA 02142-1407 USA, or telephone (617) 253-2866, fax (617) 258-5028, e-mail: journals-info@ mit.edu.

Rights and permissions: All inquiries concerning rights and permissions should be sent to Subsidiary Rights Manager, MIT Press Journals, Five Cambridge Center, Cambridge MA 02142-1407; telephone (617) 253-2864; fax (617) 258-5028; e-mail: journalsrights@mit.edu. Permission to photocopy articles for internal or personal use or the internal or personal use of specific clients is granted by The IO Foundation and the Massachusetts Institute of Technology for libraries and other users registered with the Copyright Clearance Center (CCC), provided that the fee of $\$ 8.00$ per copy is paid directly to CCC, 222 Rosewood Drive, Danvers, MA 01923. The fee code for users of the Transactional Reporting Services is $0020-8183 / 01 \$ 8.00$. For those organizations that have been granted a photocopy license with CCC, a separate system of payment has been arranged. 


\section{A Journal of \\ Political and \\ Economic Affairs \\ Edited at the University of California, San Diego \\ Published by The MIT Press}

